\title{
KONSEP DIRI DENGAN REGULASI DIRI DALAM BELAJAR PADA SISWA SMA
}

\author{
Mutia Farah $^{1}$, Yudi Suharsono ${ }^{2}$, Susanti Prasetyaningrum ${ }^{3}$ \\ Fakultas Psikologi, Universitas Muhammadiyah Malang \\ 1,2,3mutiaa24@gmail.com
}

\begin{abstract}
Abstrak. Menjadi siswa yang baik merupakan suatu keharusan agar dapat mengikuti kegiatan akademik yang ada. Regulasi diri dalam belajar adalah salah satu cara siswa untuk mengelola strategi belajarnya. Dengan ditunjang konsep diri positif siswa akan percaya pada kemampuannya, hal ini dapat mempengaruhi siswa meregulasi diri dalam belajar. Jenis penelitian ini merupakan penelitian kuantitatif. Subjek penelitian adalah siswa SMA Hang Tuah Tarakan dengan jumlah sampel 178 subjek. Teknik sampling menggunakan proportional sample. Teknik analisis menggunakan uji korelasi pearson. Penelitian ini bertujuan untuk mengetahui hubungan antara konsep diri dengan regulasi diri dalam belajar. Hasil dari penelitian ini menunjukkan adanya hubungan positif antara konsep diri dan regulasi diri dalam belajar $(\mathrm{r}=0.331 ; \mathrm{p}>0.05)$. Kontribusi konsep diri terhadap regulasi diri dalam belajar sebesar $11 \%$, dan $89 \%$ lainnya dipengaruhi oleh faktor lain.
\end{abstract}

\section{Kata kunci: Konsep diri, regulasi diri dalam belajar}

\begin{abstract}
Being a good student is an important to follow the academic activities. Self regulated learning is one of the way to manage their learning strategy. Positive self concept supported students to believe their ability, it will affect self regulated learning students. This research used quantitative research. Then, the research subject was senior high school student of Hang Tuah Tarakan with 178 subjects as the total sample. The sampling technique used proportional sampling and analysis technique using the pearson correlation test. This research aim to determine the relationship between self concept and self regulated learning. The gained results of this study showed a positive correlation between self concept in student self regulated learning $(r=0,331 ; p>0.05)$. Contribute towards self concept of $11 \%$, and $89 \%$ were affected by the other factors.
\end{abstract}

Keywords: Self concept, self regulated learning

Pendidikan merupakan hal yang sangat berperan penting dalam kehidupan manusia. Salah satu kegiatan pendidikan yang di maksud adalah bersekolah, setiap individu yang bersekolah harus melewati beberapa tingkatan agar dapat mencapai kelulusan. Di Indonesia sendiri memiliki beberapa tahapan dalam dunia pendidikan, yaitu taman kanak-kanak, sekolah dasar, sekolah menengah pertama, sekolah menengah atas, dan perguruaan tinggi.

Sekolah sebagai salah satu sarana pendidikan formal memiliki tujuan utama untuk melengkapi siswa dengan keterampilan-keterampilan regulasi diri yang dapat mendukung pembelajaran sepanjang masa atau life-long learning (Bakracevic dan Liccardo, 2010). Regulasi diri adalah proses membawa diri menuju pencapaian tujuan menjadi manusia yang utuh secara akademik, sosial, maupun eksistensial (Husna, Hidayati, \& Ariati, 2014). Regulasi diri secara akademik diharapkan muncul pada saat 
belajar, regulasi diri dalam belajar bukanlah suatu kemampuan mental atau sebuah keterampilan dalam akademik, namun lebih kepada bagaimana mengelola proses belajar individu sendiri melalui pengaturan dan pencapaian tujuan dengan mengacu pada metokognisi dan perilaku aktif dalam belajar mandiri (Zimmerman, 2002).

Menurut Ghufron \& Risnawita (2010) regulasi diri adalah upaya individu untuk mengatur diri dalam suatu aktivitas dengan mengikutsertakan kemampuan metakognisi, motivasi, dan perilaku aktif yang dimana ketiganya itu merupakan aspek regulasi diri yang diaplikasikan dalam belajar. Siswa yang dikatakan melakukan regulasi diri dalam belajar menurut Pintrich (2003) yaitu siswa yang menetapkan tujuan dan merencanakan kegiatannya, melakukan monitor dan kontrol terhadap aspek kognitif, motivasi serta tingkah lakunya dalam mencapai tujuan tersebut.

Istilah lain yang sering digunakan untuk regulasi diri dalam belajar adalah self regulated learning (Pintrich \& Groot, 1990). Berdasarkan dari beberapa pengertian tersebut regulasi diri dalam belajar merupakan kemampuan mengelola diri dalam strategi belajar yang mengacu pada metakognisi, motivasi dan perilaku untuk mencapai sebuah tujuan.

Regulasi diri dalam belajar merupakan salah satu faktor penting yang harus diperhatikan untuk mencapai hasil belajar yang baik, dimana siswa seharusnya dapat mengatur jam belajarnya sendiri, memilih kegiatan-kegiatan yang dapat menunjang prestasi akademiknya, dan menyusun strategi dalam belajar yang dapat menandakan bahwa ia mampu bertanggung jawab atas dirinya sendiri. Namun pada kenyataannya di dunia pendidikan yang muncul saat ini menunjukkan sebaliknya, dalam penelitian Pratiwi \& Laksmiwati (2016) terlihat adanya fenomena peserta didik yang kurang mandiri dalam belajar sehingga dapat menimbulkan gangguan mental setelah memasuki pendidikan lanjutan, kebiasaan belajar yang kurang baik seperti tidak betah belajar lama, belajar menjelang ujian, membolos, menyontek, dan mencari bocoran soal-soal ujian.

Tidak semua siswa memiliki dasar regulasi diri dalam belajar yang tinggi, belum lagi melihat tuntutan pendidikan jaman sekarang yang cukup sulit dengan tingginya nilai standarisasi yang diberikan, disisi lain hasil wawancara dengan guru magang di SMA Hang Tuah mengutarakan bahwa masih terdapat siswa yang lebih memilih menyalin jawaban teman saat mengerjakan tugas, tidak mau aktif bertanya, dan memilih untuk duduk diam seolah mendengarkan karena takut diminta maju untuk menjawab di papan tulis. Siswa juga jarang menggunakan fasilitas penunjang belajar yang ada seperti perpustakaan. Sebagian besar siswa yang pergi ke perpustakaan menghabiskan waktu hanya untuk membaca novel atau komik dan mencari kesejukan karena ruangan yang menggunakan air conditioner (ac).

Beberapa siswa yang belum dapat bertanggungjawab terhadap kegiatan belajarnya ditandai dengan tidak memiliki jadwal belajar rutin, mengumpulkan tugas tidak tepat waktu, bersikap pasif pada saat proses belajar mengajar di kelas dan belum memiliki rencana yang pasti untuk masa depannya. Ketika siswa melakukan penyimpangan terhadap aktivitas belajarnya, menandakan bahwa siswa memiliki regulasi diri yang rendah. Self regulation kembali pada pengaturan diri siswa terhadap pikiran, perasaan, dan perilaku yang diorientasikan untuk mencapai tujuan. Salah satu tujuan dalam pembelajaran adalah untuk membebaskan siswa dari kebutuhan mereka terhadap guru, sehingga siswa dapat terus belajar secara mandiri sepanjang hidupnya dan untuk terus belajar secara mandiri maka siswa harus menjadi seorang pembelajar berdasarkan 
regulasi diri (self regulated learner) (Latipah, 2010). Self regulated learning berperan penting dalam pembelajaran karena membantu mengarahkan siswa pada kemandirian belajar, yakni mengatur jadwal belajar, menetapkan target belajar, mencari informasi yang dibutuhkan secara mandiri, dan menentukan rencana untuk masa depannya.

Berdasarkan penelitian yang telah dilakukan Nuraini, Tawil, \& Supriyatna (2017) mengenai kemampuan regulasi diri dalam belajar siswa dengan subjek sebanyak 200 orang didapatkan hasil 48,5\% siswa berada pada kategori self regulated learning rendah, $39,5 \%$ mempunyai tingkat self regulated learning sedang, dan $12 \%$ siswa yang mempunyai self regulated learning tinggi. Dari penelitian ini menjelaskan bahwa terlihat tidak adanya usaha siswa untuk menunjukkan kemauan dalam mengatur pola belajar di SMK Yudha Karya Kota Magelang. Siswa yang self-regulated learning-nya rendah terlihat tidak memiliki perencanaan dan pengaturan waktu dalam pembelajaran, tidak memiliki strategi pembelajaran, motivasi yang rendah, dan kurang memanfaatkan sumber-sumber yang ada. Hal ini dikarenakan sebagian siswa baru mengerjakan tugas ataupun belajar menunggu moodnya bagus dan menunggu tugas yang dikerjakan dari siswa lain.

Berangkat dari perspektif sosial kognitif Thoresen dan Mahoney (dalam Zimmerman, 1989) menyatakan bahwa regulasi diri dalam belajar ditentukan oleh tiga faktor yaitu faktor individu, faktor perilaku, dan faktor lingkungan. Pada faktor individu meliputi pengetahuan diri, tujuan yang ingin dicapai, kemampuan metakognisi serta efikasi diri. Faktor perilaku meliputi behavior self reaction, personal self reaction serta environment self reaction. Sedangkan faktor lingkungan berupa lingkungan fisik maupun lingkungan sosial, baik lingkungan keluarga, lingkungan sekolah, lingkungan pergaulan dan lain sebagainya.

Pada faktor individu dikatakan bahwa pengetahuan tentang diri adalah salah satu contoh yang dapat mempengaruhi regulasi diri dalam belajar. Individu yang mengetahui tentang dirinya berarti mengetahui konsep dirinya. Konsep diri adalah gambaran penuh dari diri manusia, konsep diri adalah apa yang kita percaya tentang siapa kita gambaran total tentang kemampuan dan sifat kita (Santrock, 2005). Selain itu pendapat lain mengatakan bahwa konsep diri adalah gambaran yang dimiliki seseorang tentang dirinya, yang dibentuk melalui pengalaman-pengalaman yang diperoleh dari interaksi dengan lingkungan (Agustiani, 2006).

Siswa SMA masuk ke dalam kategori usia remaja, remaja adalah masa transisi dari periode anak ke dewasa, secara psikologis menurut Allport (dalam Sarwono, 2002) ciriciri terbentuknya konsep diri remaja yaitu: 1) Pemekaran diri sendiri yang ditandai dengan kemampuan individu untuk menganggap orang lain sebagai bagian dari dirinya juga (tumbuh perasaan ikut memiliki atau merasakan), 2) Melihat diri sendiri secara objektif yang ditandai dengan mempunyai wawasan tentang diri sendiri, 3) Memiliki falsafah hidup tertentu yang ditandai dengan mengetahui kedudukannya dalam masyarakat dan paham bagaimana harus bertingkah laku.

Menurut Burns (dalam Subaryana, 2015) konsep diri dibedakan menjadi dua, yaitu konsep diri positif dan konsep diri negatif. Konsep diri positif dapat disamakan dengan evaluasi diri yang positif seperti penghargaan diri positif. Konsep diri negatif dapat disamakan dengan evaluasi diri yang negatif seperti membenci diri, perasaan rendah diri dan tiadanya perasaan yang menghargai pribadi dan penerimaan diri. 
Fits (dalam Agustiani, 2006) menyatakan bahwa konsep diri berpengaruh kuat terhadap tingkah laku seseorang. Banyak siswa yang mengalami kegagalan dalam pelajaran bukan disebabkan oleh tingkat intelektual yang rendah atau kemampuan fisik yang lemah, melainkan oleh adanya perasaan tidak mampu untuk melakukan tugas (Dhatu \& Ediati, 2015). Ketika siswa memiliki konsep diri yang positif mereka akan berani bertanggungjawab terhadap apa yang dilakukannya, mandiri, meyakini bahwa keberhasilan maupun kegagalan tergantung dari apa yang telah diusahakan, dan memiliki cita-cita. Namun ketika siswa memiliki konsep diri yang negatif mereka akan takut akan kegagalan, tidak berani mengambil resiko, motivasi belajar dan bekerja rendah, juga kurang berani mengambil resiko terhadap tindakan yang dilakukan (Subaryana, 2015).

Berbagai penelitian yang telah dilakukan menunjukkan bahwa pandangan individu terhadap kualitas kemampuan yang individu miliki akan mempengaruhi motivasinya dalam melakukan tugas, dengan konsep diri yang positif diharapkan siswa dapat memotivasi dirinya untuk dapat meregulasi diri dalam kegiatan belajarnya dengan baik.

Hasil penelitian terdahulu yang dilakukan oleh Elsola (2016) menjelaskan bahwa terdapat hubungan searah antara konsep diri dengan motivasi berprestasi sebesar 0.676 dengan sumbangan efektif sebesar 54.23\%. Elsola memaparkan diri keluarga menjadi aspek paling berpengaruh terhadap konsep diri peserta didik, persepsi siswa yang menjadi bagian dari keluarga dan merasa diterima akan membuat siswa memiliki konsep diri yang positif, konsep diri yang positif ini dapat memotivasi dan mempengaruhi perilaku siswa yang salah satunya dalam hal belajar. Hal ini dikarenakan adanya perasaan senang siswa yang mendapat perhatian juga kasih sayang dari orang tua.

Pada dasarnya secara perkembangan karakteristik konsep diri remaja menjadi lebih introspektif dan cenderung menolak adanya pandangan negatif dalam diri mereka. Sebab dengan konsep diri yang positif seseorang akan bersikap optimis, berani mencoba hal-hal baru, berani sukses dan berani pula gagal, penuh percaya diri, antusias, merasa diri berharga, berani menetapkan tujuan hidup, serta bersikap dan berpikir secara positif (Desmita, 2009). Maka dari itu remaja akan melakukan yang terbaik untuk membentuk pandangan positif terhadap dirinya. Ketika siswa melakukan upaya-upaya untuk membentuk pandangan positif tersebut selain siswa dapat membentuk konsep diri yang positif, siswa juga akan mulai terbiasa membentuk kebiasaan belajar seperti memunculkan regulasi diri dalam belajar.

Kemudian terdapat juga hasil penelitian jurnal yang dilakukan oleh Novilita dan Suharnan (2013) dengan judul konsep diri adversity quotient dengan kemandirian belajar siswa didapatkan hasil ada hubungan positif antara konsep diri dan tingkat kemandirian belajar siswa dengan nilai 0,604. Dari hasil analisis tersebut dapat diketahui bahwa konsep diri yang positif diperlukan untuk sebagai salah satu faktor internal yang dapat mempengaruhi kemandirian belajar, karena dengan memiliki konsep diri yang positif berarti siswa sudah mampu mengenali hubungan yang positif dengan kemandirian belajar.

Pada penelitian terdahulu mayoritas peneliti mengangkat tema konsep diri mempengaruhi prestasi belajar, namun sebelum mendapatkan prestasi dalam belajar tersebut siswa akan melewati beberapa proses untuk mencapai hasil prestasi itu sendiri. Ketika proses itu berhasil dijalani dengan baik maka akan menghasilkan prestasi belajar yang baik, namun ketika proses tersebut tidak mampu untuk dilaksanakan dengan baik maka hasilnya juga 
kurang memuaskan. Proses tersebut adalah regulasi diri siswa dalam belajar. Maka dari itu hipotesa dari penelitian ini adalah adanya hubungan antara konsep diri dengan regulasi diri dalam belajar siswa SMA Hang Tuah Tarakan.

Tujuan dari penelitian ini yaitu untuk mengetahui hubungan antara konsep diri dengan regulasi diri dalam belajar pada siswa SMA Hang Tuah Tarakan. Manfaat teoritis dari penelitian ini yaitu agar menambah wawasan serta sebagai acuan referensi untuk penelitian dalam bidang psikologi selanjutnya. Manfaat praktis dari penelitian ini yaitu untuk memberikan informasi kepada pembaca mengenai pentingnya konsep diri dalam membentuk regulasi dalam belajar siswa.

\section{METODE}

Populasi subjek dari penelitian ini adalah siswa SMA Hang Tuah Tarakan pada kelas X XI yang berjumlah 360 orang siswa. Dari jumlah populasi tersebut menurut tabel Isaac dan Michael dengan menggunakan tingkat kesalahan 5\% didapatkan hasil 178 orang siswa untuk dijadikan sampel. Peneliti menggunakan proportional sample untuk mengambil data dengan cara memilih sampel dari setiap strata kelas secara seimbang atau sebanding dengan banyaknya subjek dalam masing-masing strata kelas lainnya.

Terdapat dua varibel yang akan diteliti, yaitu variabel terikat (Y) berupa regulasi diri dalam belajar dan variabel bebas $(\mathrm{X})$ berupa konsep diri. Regulasi diri dalam belajar yang dimaksud dalam penelitian ini adalah kemampuan mengelola diri dalam strategi belajar yang mengacu pada metakognisi, motivasi dan perilaku untuk mencapai sebuah tujuan belajar. Aspek regulasi diri dalam belajar meliputi regulasi kognisi, regulasi motivasi, dan ragulasi perilaku. Regulasi diri dalam belajar ini diukur menggunakan skala yang diadaptasi dari penelitian Ghea Monalisa (2018), yaitu skala A Manual for the Use of the Motivated Strategies for Learning Questionnaire (MSLQ) yang dikembangkan oleh Pintrich, Smith, Garcia, McKeachie (1991). Skala ini memiliki 23 item favorable yang terdiri dari 3 aspek berlandaskan teori Zimmerman \& Pons (1990), yaitu aspek metakognisi (6 item), aspek motivasi (3 item), dan aspek perilaku (14 item). Pada skala ini diketahui indeks validitas berkisar antara 0.340 - 0.765 dan indeks reliabilitas 0.914 .

Konsep diri yang dimaksud dalam penelitian ini adalah pandangan seseorang terhadap dirinya sendiri mulai dari fisik hingga psikologis yang bersumber dari keyakinan diri dan terbentuk oleh interaksi dengan lingkungan. Skala ini memiliki 17 item favorable dan unfavorable yang terdiri dari 4 aspek berlandaskan teori Berzonsky (dalam Rahmaningsih \& Martani, 2014), yaitu aspek fisik (4 item), aspek sosial (4 item), aspek moral (2 item), dan aspek psikis (7 item). Pada skala ini diketahui indeks validitas berkisar antara 0.206 - 0.658 dan indeks reliabilitas sebesar 0.840 .

Instrumen pada penelitian ini menggunakan skala A Manual for the Use of the Motivated Strategies for Learning Questionnaire (MSLQ) dan skala konsep diri yang disusun oleh peneliti dengan model likert. Terdapat empat kategori jawaban pada skala, yaitu sangat setuju (SS), setuju (S), tidak setuju (TS), dan sangat tidak setuju (STS).

Beberapa tahap dalam penelitian ini, yaitu: (1) tahap pertama dimulai dengan tahap persiapan, yaitu melakukan proses perumusan masalah yang akan diteliti, menentukan 
variabel penelitian, mencari referensi terkait teori yang akan diperdalam sebagai dasar penelitian, menentukan dan menyiapkan instrumen penelitian yaitu skala konsep diri dan regulasi diri dalam belajar. Kemudian sebelum melakukan penelitian, peneliti melakukan try out atau uji coba skala konsep diri dan regulasi diri dalam belajar pada 34 siswa SMA; (2) tahap kedua yaitu pelaksanaan. Peneliti mengambil data penelitian dengan menyebar skala kepada 178 siswa kelas X - XI yang bersekolah di SMA Hang Tuah Tarakan. Hasil jawaban subjek untuk masing-masing skala kemudian diinput sesuai pengkodean dari skala likert; (3) tahap terakhir adalah tahap analisa data. Peneliti menganalisa hasil yang didapatkan dari subjek. Data-data yang telah diinput tersebut kemudian diolah menggunakan program analisa statistik bernama Statistic Package For Social Science 25 (SPSS). Kemudian peneliti menarik kesimpulan dari hasil penelitian.

\section{HASIL PENELITIAN}

Setelah dilakukan pengambilan data sebanyak 178 subjek siswa kelas X dan XI SMA Hang Tuah Tarakan, dapat diketahui bahwa 92 atau 51.6\% subjek siswa berjenis kelamin perempuan dan 86 atau $48.3 \%$ subjek siswa berjenis kelamin laki-laki. Pada kelas X dan XI siswa berjumlah sama atau sebanding yaitu 89 orang siswa dengan presentase $50 \%$ pada kedua tingkatan tersebut.

\section{Tabel 1. Kategori Konsep Diri dan Regulasi Diri dalam Belajar}

\begin{tabular}{|c|c|c|c|c|}
\hline \multirow{2}{*}{ Kategori } & \multicolumn{2}{|c|}{ Konsep Diri } & \multicolumn{2}{|c|}{ Regulasi Diri dalam Belajar } \\
\hline & Positif & Negatif & Tinggi & Rendah \\
\hline Inter & T-score $>50$ & $\mathrm{~T}$-score $\leq 50$ & T-score $>50$ & $\mathrm{~T}$-score $\leq 50$ \\
\hline Frekuensi & 92 & 86 & 95 & 83 \\
\hline Presentase & $51.7 \%$ & $48.3 \%$ & $53.4 \%$ & $46.6 \%$ \\
\hline
\end{tabular}

Berdasarkan dari tabel di atas dapat diketahui bahwa subjek siswa SMA Hang Tuah yang memiliki konsep diri positif yaitu 92 atau $51.7 \%$ dan 86 atau $48.3 \%$ memiliki konsep diri negatif. Dari hasil tersebut dapat dilihat jika sebagian dari subjek sudah memiliki konsep diri yang positif, hal ini menggambarkan bahwa subjek mengetahui kemampuan yang dimiliki, mampu beradaptasi dengan lingkungan, bertanggungjawab terhadap kegiatan yang dijalani, ingin berusaha, dan mampu mencari solusi atas permasalahan yang ada.

Selain itu hasil yang didapatkan dari tabel di atas adalah subjek siswa yang memiliki tingkat regulasi diri dalam belajar tinggi sebanyak 95 atau $53.4 \%$ siswa dan 83 atau $46.6 \%$ siswa memiliki regulasi diri dalam belajar rendah. Dari hasil tersebut dapat dilihat jika sebagian besar subjek menyadari pentingnya belajar, memiliki keinginan untuk menjadi pelajar yang lebih baik dari sebelumnya, dan mencoba melakukan kegiatan yang menunjang kegiatan pembelajaran.

Pada hasil uji normalitas menggunakan frequencies didapatkan hasil skewness konsep diri -0.30769231 dan skewness regulasi diri dalam belajar -0.95054945 , lalu hasil kurtosis konsep diri -1.77348066 dan kurtosis regulasi diri dalam belajar - 1.34530387 . Syarat data berdistibusi normal apabila nilai skewness dan kurtosis berada pada rentang 
(-2 hingga +2). Tujuan dari uji normalitas data ini adalah untuk menilai normal atau tidaknya sebaran data pada sebuah variabel agar dapat menentukan uji korelasi yang tepat setelahnya. Disimpulkan bahwa data di atas berdistribusi normal karena berada pada rentang ( -2 hingga +2$)$. Data yang berdistribusi normal dapat dianalisis menggunakan uji korelasi pearson.

\section{Tabel 2. Uji Korelasi}

\begin{tabular}{cc}
\hline & Indeks Analisis \\
\hline Koefisien Korelasi (R) & 0.331 \\
Koefisien Determinasi ( $\left.\mathrm{R}^{2}\right)$ & 0.110 \\
Nilai Signifikansi/sig. (2-tailed) & 0.000 \\
\hline
\end{tabular}

Berdasarkan dari tabel didapatkan hasil uji korelasional pearson memiliki nilai sig. (2tailed) 0.000 dan koefisien korelasi sebesar 0.331. Syarat antar variabel dikatakan berhubungan, jika nilai sig. (2-tailed) $<0.05$. Pada tabel terlihat nilai sig. (2-tailed) adalah 0.000 yang berarti $<0.05$ dan bermakna kedua variabel berkorelasi atau berhubungan positif sebesar $33.1 \%$. Korelasi kedua variabel adalah cukup berkorelasi. Semakin positif konsep diri yang dimiliki siswa maka semakin tinggi pula regulasi diri dalam belajar siswa, sebaliknya semakin negatif konsep diri yang dimiliki siswa maka semakin rendah pula regulasi diri dalam belajar siswa. Selain itu pada nilai koefisien determinasi sebesar 0.110 menunjukkan bahwa variabel konsep diri memiliki sumbangan efektif sebesar $11 \%$ terhadap variabel regulasi diri dalam belajar dan sisanya sebesar $89 \%$ dipengaruhi oleh faktor lain.

\section{DISKUSI}

Dari hasil analisis data yang telah dilakukan, didapatkan hasil bahwa kedua variabel yaitu konsep diri dan regulasi diri dalam belajar berkorelasi positif dengan nilai sig. (2-tailed) $0.000<0.05$ yang artinya hasil analisis menunjukkan semakin positif konsep diri yang dimiliki maka semakin tinggi pula regulasi diri dalam belajar siswa. Sebaliknya, semakin negatif konsep diri yang dimiliki siswa maka semakin rendah pula regulasi diri dalam belajar yang dilakukan siswa. Sehingga hasil hipotesis dari penelitian ini diterima, yaitu dengan terbuktinya hipotesa penelitian bahwa kedua variabel berkorelasi dan konsep diri yang dimiliki siswa dapat mempengaruhi regulasi diri dalam belajar siswa.

Pada hasil penelitian, sebagian siswa memiliki konsep diri positif yaitu 51.7\%. Montana (2001) menjelaskan bahwa seseorang yang memiliki konsep diri tinggi akan memandang positif terhadap kemampuan yang ada pada dirinya, memiliki cita-cita, dan meyakini bahwa keberhasilan tergantung dari usaha yang telah dilakukan. Maka dari itu siswa akan berusaha mengikuti pembelajaran dengan baik dan teratur sehingga terbentuklah regulasi diri dalam belajar siswa yang ditandai dengan kesadaran, keinginan, dan aktivitas penunjang belajarnya.

Pemahaman siswa terhadap kemampuannya akan membawa seseorang pada pengembangan potensi yang dimiliki, begitu juga dengan pemahaman akan kelemahan diri yang dapat membawa siswa pada peningkatan potensi dan mampu mengatasi kelemahan diri. Pemahaman terhadap kemampuan akademik yang ada dalam diri 
individu juga akan mempengaruhi bagaimana individu menetapkan strategi belajar yang tepat untuk diri sendiri agar tujuan dari belajarnya dapat tercapai (Rumahorbo, 2014)

Moss dan Kegen (dalam Calhoun dan Acocella, 1990) mengatakan bahwa keinginan dalam diri individu untuk berhasil dipengaruhi oleh konsep diri seorang individu. Maka apabila seseorang tidak yakin atau bahkan memandang buruk potensi yang ada dalam dirinya, individu tersebut tidak akan termotivasi untuk mengembangkan potensi dirinya dalam proses belajar. Oleh karena itu konsep diri dianggap sebagai pemegang peran kunci dalam pengintegrasian kepribadian individu di dalam memotivasi tingkah laku, terutama saat belajar (Burns, 2002).

Pendapat tersebut sesuai dengan pernyataan Bandura (dalam Alwisol, 2009) yang memaparkan bahwa struktur kepribadian pada konsep diri saling determinis menempatkan semua hal saling berinteraksi, pusatnya ialah sistem self yang mengacu ke struktur kognitif kemudian memberi pedoman mekanisme dan seperangkat fungsi-fungsi persepsi, evaluasi dan pengaturan tingkah laku. Sehingga jika fungsi-fungsi persepsi dan evaluasi baik, maka tingkah laku yang nampak, khususnya regulasi diri dalam belajar akan terbentuk.

Penelitian terdahulu yang berkaitan dengan penelitian ini adalah milik Dhatu \& Ediati (2015) dengan judul konsep diri akademik dan motivasi berprestasi pada siswa SMPN 24 Purworejo, didapatkan hasil nilai korelasi sebesar 0,283. Dari hasil analisis tersebut dapat diketahui bahwa perbedaan konsep diri akademik yang memandang dirinya positif akan menganggap keberhasilannya sebagai adanya kemampuan, sedangkan siswa yang memandang dirinya negatif menganggap keberhasilan yang dicapai hanya sebuah kebetulan. Siswa yang berprestasi tinggi akan menganggap prestasi itu sebagai kemampuan sedangkan siswa yang kurang berprestasi akan memandang diri mereka sebagai orang yang tidak mempunyai kemampuan. Sehingga regulasi diri dalam belajar siswa akan terpacu ketika siswa menganggap dirinya mampu.

Dilihat dari hasil penelitian menunjukkan bahwa sebagian besar siswa memiliki regulasi diri dalam belajar yang tinggi yaitu 53.4\%. Siswa yang memiliki regulasi diri dalam belajar merupakan siswa yang mampu menyusun strategi belajarnya sendiri, siswa yang mandiri ini akan memperlihatkan perilaku yang eksploratif, mampu mengambil keputusan, percaya diri, dan kreatif. Selain itu juga mampu bertindak kritis, tidak takut berbuat sesuatu, mempunyai kepuasan dalam melakukan aktifitasnya, mampu menerima realitas serta dapat memanipulasi lingkungan, mampu berinteraksi dengan teman sebaya, terarah pada tujuan, dan mampu mengendalikan diri dalam hal belajar (Monks dkk, 2006)

Regulasi diri dalam belajar siswa yang mengacu pada metakognisi, motivasi dan perilaku untuk mencapai sebuah tujuan yaitu belajar akan membuahkan hasil yang baik. Seperti pendapat yang dikemukakan oleh Burns (1993) keberhasilan belajar tidak hanya ditentukan oleh kecerdasan tetapi juga oleh variabel non kognitif seperti kepribadian dan konsep diri. Konsep diri merupakan hal penting dalam membentuk tingkah laku, sehingga terkait dengan dunia pendidikan .

Konsep diri positif yang dimiliki siswa akan menunjang regulasi diri dalam belajar siswa. Dilihat dari hasil penelitian yang menunjukkan ada hubungan yang cukup signifikan antara konsep diri dengan regulasi diri dalam belajar siswa, semakin positif konsep diri 
yang dimiliki siswa maka semakin berpengaruh pula dengan cara siswa meregulasi dirinya dalam belajar. Sehingga wajar jika konsep diri memberikan sumbangan efektif pada regulasi diri dalam belajar sebesar $11 \%$, yang berarti sebesar $89 \%$ lainnya dipengaruhi oleh faktor lain yang tidak diteliti pada penelitian ini.

Desmita (2009) mengemukakan bahwa banyak pendidik yang membuktikan hubungan positif yang kuat antara konsep diri positif dengan prestasi belajar di sekolah. Siswa yang memiliki konsep diri positif memperlihatkan prestasi yang baik di sekolah, atau siswa yang berprestasi tinggi di sekolah memiliki penilaian diri yang tinggi, serta menunjukan hubungan antar pribadi yang positif pula.

Dengan demikian konsep diri berperan sebagai pedoman dalam berinteraksi dengan lingkunganya. Siswa yang memiliki konsep diri yang baik akan memunculkan persepsi diri yang positif sehingga mampu membangkitkan motivasi untuk berperilaku yang baik, salah satunya seperti regulasi diri dalam belajar.

Konsep diri dipengaruhi oleh beberapa faktor, Fitts (dalam Agustiani, 2006) membeberkan tiga hal yaitu: 1) Pengalaman, terutama pengalaman interpersonal individu yang memunculkan perasaan positif dan perasaan berharga, 2) Kompetensi atau kemampuan dalam area yang dihargai oleh individu dan orang lain, 3) Aktualisasi diri, atau implementasi dan realisasi dari potensi pribadi yang dimiliki sebenarnya.

Seseorang yang memiliki kemampuan regulasi diri dalam belajar yang baik akan mampu menonitor dirinya. Individu tersebut dapat mengidentifikasi dan menganalisa kemampuan-kemampuan yang dimilikinya baik kelebihan maupun kekurangan dalam memahami pelajaran. Setelah mampu memonitor, individu dengan regulasi diri dalam belajar yang baik akan mampu melakukan perencanaan terhadap proses belajarnya. Individu tersebut mampu memilih tujuan dan strategi belajar yang sesuai dengan gambaran dirinya. Selanjutnya, individu tersebut akan melaksanakan rencana belajarnya dan juga mampu mengevaluasi pelaksaan rencana tersebut. Individu akan menilai pelaksanaan rencana tersebut. Penilaian diri atas rencana belajar akan memunculkan keinginan individu untuk mempertahankan atau memperbaiki tujuan dan strategi yang telah dilakukan guna meraih hasil belajar yang diharapkan (Saraswati, 2016)

Namun tidak selalu siswa yang menerapkan regulasi diri dalam belajar memiliki konsep diri yang positif. Seperti yang terlihat pada hasil kategorisasi, terdapat 3 siswa yang memiliki konsep diri negatif tetapi tetap tinggi regulasi diri dalam belajarnya. Hal ini dikarenakan pada siswa sekolah menengah atas (SMA) untuk membentuk perilaku regulasi diri dalam belajar, masih dipengaruhi oleh adanya dukungan sosial dari orangorang di sekitarnya (Ryan \& Deci, 2000).

Selain itu konsep diri yang dimiliki masih belum terbentuk secara utuh karena banyak dipengaruhi oleh significant others (guru dan orang tua). Seiring dengan waktu, konsep diri seseorang akan terbentuk lebih utuh pada saat ia beranjak dewasa ketika ia telah memiliki kemandirian lebih dalam berperilaku dan mengambil keputusan (Mardhiyah \& Indianti, 2018) 


\section{SIMPULAN DAN IMPLIKASI}

Berdasarkan hasil penelitian dapat dikatakan bahwa terdapat adanya hubungan positif yang cukup signifikan antara konsep diri dengan regulasi diri dalam belajar. Hal ini menunjukkan jika semakin positif konsep diri yang dimiliki siswa, maka semakin tinggi pula regulasi diri dalam belajar siswa. Sebaliknya, semakin negatif konsep diri yang dimiliki siswa, maka semakin rendah pula regulasi diri dalam belajar siswa.

Implikasi untuk peneliti selanjutnya, disarankan agar melakukan: 1) penelitian lebih lanjut mengenai pengaruh konsep diri pada regulasi diri dalam belajar, 2) menggunakan variabel lain yang dapat memunculkan regulasi diri dalam belajar siswa seperti self efficacy, goals, intervensi pelatihan manajemen diri, dukungan sosial, dan lingkungan belajar, 3) mempersiapkan alat ukur konsep diri dan regulasi diri dalam belajar yang sesuai.

Implikasi untuk siswa yaitu dapat meningkatkan regulasi diri dalam belajar dengan memahami kelemahan yang dimiliki ketika belajar, aktif bertanya jika ada materi yang kurang dipahami, dapat menetapkan tujuan yang diharapkan dengan jelas, dan mencoba menggunakan metode belajar yang mudah untuk dimengerti.

\section{REFERENSI:}

Acocella, J. R., \& Calhoun, J. F. (1990). Psychology of adjustment human relationship (3th ed). New York : McGraw-Hill.

Agustiani, H. (2006). Psikologi perkembangan: pendekatan ekologi kaitannya dengan konsep diri dan penyesuaian diri pada remaja. Bandung: Refika Aditama.

Alwisol. (2009). Psikologi kepribadian (Ed. Revisi). Malang: UMM Press.

Arikunto, S. (2006). Prosedur penelitian: Suatu pendekatan praktik. Jakarta: Rineka Cipta.

Astuti, E. D. (2016). Hubungan konsep diri dengan motivasi belajar siswa kelas viii di madrasah tsanawiyah negeri (mtsn) bukit raya unggul dan berkarakter (uk) pekanbaru. Skripsi, Universitas Islam Negeri Sultan Syarif Kasim Riau.

Bakracevic, K.V., \& Licardo, M. (2010). How cognitive, metacognitive, motivational and emotional self-regulation influence school performance in adolescence and early adulthood. Educational Studies Departement of Psychology at Marobor University, 36(3), 259-268.

Burns, R. B. (1993). Konsep diri (teori, pengukuran, perkembangan, dan perilaku). alih bahasa: eddy. Jakarta: Arcan.

Burns, R. B. (2002). Konsep diri (teori pengukuran, perkembangan dan perilaku). Jakarta: Arcan.

Desmita. (2009). Psikologi perkembangan peserta didik. Bandung: Remaja Rosdakarya. 
Dhatu, O. M., \& Ediati, A. (2015). Konsep diri akademik dan motivasi berprestasi pada siswa SMPN 24 Purworejo. Jurnal Empati, 4(4).

Elsola, D. A. N. (2016). Korelasi regulasi dan konsep diri dengan motivasi berprestasi siswa pada mata pelajaran ipa kelas iv. Skripsi, Program Studi Pendidikan Guru Sekolah Dasar Universitas Negeri Yogyakarta.

Ghufron, M.N., \& Risnawita, R. (2010). Teori-teori Psikologi, Yogyakarta, Ar-Ruzz Media.

Husna, A. N., Hidayati, F. N. R., \& Ariati, J. (2014). Regulasi diri mahasiswa berprestasi. Jurnal Psikologi Universitas Diponegoro, 13(1), 50-63.

Hurlock, E. B. (1978). Perkembangan anak. (Terj. Dr. Med Meitasari Tjandrasa). Jakarta: Erlangga.

Hurlock, E. B. (1990). Psikologi Perkembangan, Suatu Pendekatan Sepanjang Rentang Kehidupan. (Terj. Istiwidayanti, dkk). Jaklarta : Erlangga.

Latipah. (2010). Strategi self regulated learning dan prestasi belajar: Kajian meta analisis. Jurnal Psikologi Universitas Islam Negeri Sunan Kalijaga, 37(1), 110-129.

Mardhiyah, K. Z., \& Indianti, W. (2018). Mediasi Konsep diri akademik dalam peran regulasi diri belajar terhadap komitmen kepada pilihan karir siswa SMA. Jurnal Psikologi Insight, 2(2).

Monalisa, G. (2018). Hubungan antara regulasi diri dalam belajar dan efikasi diri pengambilan keputusan karir pada mahasiswa skripsi. Skripsi, Program Studi Psikologi Universitas Islam Indonesia, Yogyakarta.

Monks, F. J., Haditono, S. R., Knoers, A.M.P. (2006). Psikologi Perkembangan. Yogyakarta: Gadjah Mada University Press.

Montana, (2001). "Positive \& Negative Self Concept", dapat ditelusuri www.montana.edu. (www.4h/Self.Html-8k)

Novilita, H., \& Suharnan. (2013). Konsep diri adversity quotient dan kemandirian belajar siswa. Jurnal Psikologi, 8(1).

Nuraini, P., Tawil, \& Supriyatna, A. (2017). Kemampuan self regulated learning siswa di SMK Yudha Karya Kota Magelang. Paper of the 6th URECOL. Diperoleh dari http://journal.ummgl.ac.id/index.php?journal=urecol\&page=article\&op=view\&pa th $\% 5 \mathrm{~B} \% 5 \mathrm{D}=1456 \&$ path $\% 5 \mathrm{~B} \% 5 \mathrm{D}=805$

Nurliana, Y. (2015). Konsep diri remaja (siswa kelas X SMA). Disajikan pada Seminar Psikologi dan Kemanusiaan di Psychology Forum Universitas Muhammadiyah Malang, Malang.

Pintrich, P. R. (2003). A motivational science perspective on the role of student motivation in learning and teaching contexts. Journal of Educational Psychology, 95(4), 667-686. 
Pintrich, P.R., \& De Groot, E.V. (1990). Motivational and self-regulated learning components of classroom academic performance. Journal of Educational Psychology, 82(2), 33-40.

Pratiwi, I.D., \& Laksmiwati, H. (2016). Kepercayaan diri dan kemandirian belajar pada siswa SMA X. Jurnal Psikologi Teori dan Terapan 7(1).

Rahmaningsih, N, D., \& Martani, W. (2014). Dinamika konsep diri pada remaja perempuan pembaca teenlit. Jurnal Psikologi 41(2).

Rakhmat, J. (2007). Psikologi komunikasi (Ed. revisi). Bandung: PT. Remaja Rosda Karya.

Reski., Taufik., Ifdil. (2017). Konsep diri dan kedisiplinan belajar siswa. Jurnal Educatio $3(2)$.

Rumahorbo, A. W. (2014). Hubungan antara konsep diri akademik dengan self regulated learning pada mahasiswa penghuni asrama mahasiswa universitas sumatera utara. Skripsi, Program Studi Psikologi Universitas Sumatera Utara.

Ryan, R. M., \& Deci, E. L. (2000). Self determination theory and the facilittion of intrinsic motivation, social development, and well being. American Psychologist, 55(1), 67-78.

Santrock, J, W. (2005). Adolescence. Eleven edition. Mac Graw hill. New York.

Saraswati, P. (2016). Kontribusi self regulated learning dan kecerdasan emosi dalam konsentrasi belajar. Jurnal Psikologi Perseptual.

Sarwono, S. W. (2002). Psikologi remaja. Jakarta: RajaGrafindo Persada.

Savira, F., \& Suharsono, Y. (2013). Self regulated learning dengan prokrastinasi akademik pada siswa akselerasi. Jurnal Ilmiah Psikologi Terapan 1(1).

Sihaloho, L.H. (2016). Hubungan iklim sekolah dan kematangan emosional dengan self regulated learning pada siswa SMAN 1 Stabat. Tesis, Program Pascasarjana Universitas Medan Area, Medan.

Subaryana. (2015). Konsep diri dan prestasi belajar. Jurnal Dinamika Pendidikan Dasar $7(2)$.

Sugiyono. (2006). Statistika untuk penelitian. Bandung: Alfabeta.

Tumanggor, H. R., Sunawan., \& Purwanto, E. (2018). Keefektifan layanan informasi karir berbantuan website untuk meningkatkan perencanaan karir siswa SMA di Kota Tarakan. Jurnal Bimbingan dan Konseling Ar-Rahman 4, (1).

Wolters, C.A., Pintrich, P.R., \& Karabenick, S.A. (2003, April). Assesing academic selfregulated learning. Paper prepared for the conference on indicators of positive development: Definitions, Measures, and Prospective Validity. Sponsored by Child Trends, National Institutes of Health. Retrieved from 
https://www.childtrends.org/wp-content/uploads/2013/05/Child_Trends2003_03_12_PD_PDConfWPK.pdf

Zimmerman, B. J. (1989). A social cognitive view of self-regulated academic learning. Journal of Educational Psychology, 81(3), 329-339.

Zimmerman, B. J., \& Pons, M. M. (1990). Student differences in self regulated learning: relating grade, sex, and giftedness to self-efficacy and strategy use. Journal of educational psychology, 82(1), 51-59.

Zimmerman, B. J. (2002). Becoming a self-regulated learner: an overview. Theory Into Practice, 41(2). Retrieved from https://www.researchgate.net/publication/ 237065878_Becoming_a_Self-Regulated_Learner_An_Overview 